\title{
Human Resource Inputs in Students Industrial Work Experience Scheme for Skill Acquisition in Agricultural Education Programme in Nigerian Colleges of Education
}

\author{
Prof Famiwole R. O. \\ Department of Vocational and Technical Education \\ Faculty of Education, Ekiti State University, Ado Ekiti, Nigeria. \\ Fabamise D. B. \\ Department of Vocational and Technical Education \\ Faculty of Education, Ekiti State University, Ado Ekiti, Nigeria. \\ Owolawi B . F. \\ Department of Vocational and Technical Education \\ Faculty of Education, Ekiti State University, Ado Ekiti, Nigeria.
}

\begin{abstract}
The purpose of this study was to explore the human resource inputs in Students Industrial Work Experience Scheme (SIWES) such as institution supervisors, SIWES coordinators, industry-based supervisors and ITF personnel for effective implementation of the programme and skill acquisition. Students Industrial Work Experience Scheme (SIWES) is a skill training programme designed to expose and prepare students in Colleges of Education for the industrial work situation they are likely to meet after graduation. Growing public demand in the provision of trained and skilled indigenous manpower, needed by industry and commerce in the past two decades have made it imperative that Colleges of Education administrators pay attention to the potential impact of SIWES on skill development. The skill development and acquisition gained by the Agricultural Education students in Colleges of Education in SIWES is pivoted on human resource inputs: right placement of the students by the SIWES coordinators; effective monitoring and supervision by the institution supervisors and Industrial Training Fund (ITF) personnel and skill-acquiring training given by the industry-based supervisors. The inputs of these human resources are inevitable in skill development and acquisition in SIWES provided they are available, adequate and functional in imparting the needed training into the students. Concepts on Students Industrial Work Experience Scheme (SIWES), skill development and acquisition, human resource inputs needs in SIWES among others were discussed. Constraints to effective human resource inputs in enhancing skill acquisition were also highlighted. This paper concluded that the responsibilities of the human resource inputs in ensuring skill development and acquisition needed to be looked into. Thorough supervision of students on SIWES is needed for better implementation of SIWES and effective skill acquisition. Suggestions were made to this effect.
\end{abstract}

Keywords: Human Resource Inputs, SIWES, Skill Acquisition, Agricultural Education Programme, Colleges of Education, Nigeria.

DOI: $10.7176 / \mathrm{JEP} / 11-16-15$

Publication date:June 30th 2020

Introduction

Students' Industrial Work Experience Scheme (SIWES) is a skill development programme established by Industrial Training Fund (ITF) in 1973 with the headquarters in Jos Nigeria. It is the accepted skills training programme in institutions of higher learning in Nigeria that forms part of the approved academic requirement in various diploma and degree programmes. It is meant to enable students in Colleges of Education and other 
tertiary institutions in Nigeria acquire technical skills and experience for professional development in their course of study as it bridges the gap between theory and practice (Ogbuanya, Njoku and Ogunkelu, 2018). There has been much concern on the quality of practical experience the students gain on the job market in their industrial attachment which has resulted to unemployment since the objectives of the programme has not been met.

The high rate of unemployment among the graduates of Agricultural Education programme of Colleges of Education in Nigeria is as a result of lack of skill acquisition. Ogbuanya et.al., 2018, opined that this growing impression attracts a compelling need on SIWES, to explore the human resource inputs that aid in training the Agricultural Education students in SIWES for skill development and acquisition. Osinem (2008) affirmed that human resource inputs into Agricultural Education and Training are personnel such as teacher, technologist, technician and farm attendants that assist in imparting knowledge and skills to learners.

This is a replica of the human resource inputs needed in Students Industrial Work Experience Scheme (SIWES). They are SIWES coordinators, institution supervisors, industry-based supervisors and Industrial Training Fund (ITF) personnel. Each of these has a specific role to play in enhancing effective implementation of Students Industrial Work Experience Scheme. It has been observed that the objectives of establishing the scheme have not been met. This is because there perceived to be low level of skill acquisition by the graduates of Agricultural Education in most of the Colleges of Education. This could be as a result of non-availability, inadequacy and non-functionality of the human resource inputs during SIWES.

For example, it is the duty of the SIWES coordinators to be available for the students to secure a relevant place to their field for them for the training. In a situation where a place is secured at times, most students are not in the department relevant to their field of study. This warranted Taiwo (2016) to state that securing a placement in an organization that has modern equipment and facilities is very difficult, therefore most students settled for organizations that are not well equipped for the training, This has to be looked into in Nigerian Colleges of Education.

\section{Colleges of Education in Nigeria}

College of Education is one of the tertiary institutions in Nigeria, where teachers are trained to acquire Nigerian Certificate in Education. It is an institution of learning that prepares teachers for a minimum of three years to make them qualify to teach subjects in Education and specialized courses such as Mathematics Education, English Education and Agricultural Education among others. Agricultural Education is one of the programmes in Colleges of Education in the Southwest, Nigeria. Olaitan, (2017) described it as a field of study where candidates are trained pedagogically and technically to acquire knowledge, skill and attitudes in production agriculture.

\section{Agricultural Education Programme in Colleges of Education}

Agricultural Education as opined by Famiwole \&Adu (2013), is a systematic programme of instruction for the secondary school and post-secondary school youths for the purpose of improving agricultural methods, skills, competencies and interest. Agricultural Education as defined by Olaitan, (2017) is the training aspect of agriculture for producing agricultural personnel through the school. It is a type of education for training people in the act of learning and also in the pedagogy. The philosophy of NCE Agricultural Education programme is tied with the National Philosophy on Agricultural Education programme for self-reliance based on the provision of teachers endowed with a balanced approach between principles and practice of agriculture for academic and vocational ends (NCCE, 2009).

The objectives of Agricultural Education programme as stated by the National Commission for Colleges of Education Minimum Standard (2009) is to:

- $\quad$ prepare graduates with right attitudes and knowledge/professional competence in vocational agriculture;

- $\quad$ provide teachers who will be capable of motivating students to acquire interest in and aptitude for agriculture;

- develop in the student-teacher the appropriate communication skills for effective transmission of agricultural information to the students in the context of their environment;

- $\quad$ equip the student-teacher with adequate knowledge and ability to establish and manage a model school farm effectively; and

- $\quad$ provide a sound background to enhance further academic and professional progression of the studentteacher.

Agricultural Education is a three academic year programme in Nigeria Colleges of Education which is aimed at producing competent, skilled and professionally qualified teachers for both primary and junior secondary schools. At the end of the second year of the three years programme, students in the School of Vocational and Technical Education, such as Business Education, Technical Education and Agricultural 
Education are usually attached to various industries and businesses for a Student Industrial Work Experience Scheme (SIWES) which is financed by Industrial Training Fund (ITF), a Federal Government controlled agency.

\section{Students Industrial Work Experience Scheme (SIWES) in Agricultural Education Programme.}

The Students Industrial Work Experience Scheme (SIWES) is a skill training programme designed to expose and prepare students in Colleges of Education for the industrial work situation they are likely to meet after graduation (Akerejola, 2008) as cited in Abraham-Ibe (2014). It is also a planned and structural programme based on stated and specific career objectives which are geared towards developing the occupational competencies of participants. It is one of the programmes declared by the Federal Government that involves participation by learners in work situation while still learning in school.

Students Industrial Work Experience Scheme (SIWES) is also a learning experience which provides learners the opportunity to acquire practical experience in their trades, using the newest technology. According to Aregbesola (2018), work experience is the best teacher. Every student of Agricultural Education is expected to have a good practical experience programme that is well supervised. The need for this arises as a result of global competitiveness in the industry and also the need to produce graduates of TVET who have the skills needed in the industries in Nigeria and the world at large (Njoku, 2014).

The scheme is meant to bridge the gap between classroom theory and the world of work. It is a tripartite programme involving the students, the tertiary institutions and the employers of labour. According to James and Robinson (2017) and ITF (2004), SIWES was established with the following specific objectives summarized by the federal government in its Gazette of April, 1978. The objectives are to:

1. Provide an avenue for students to acquire industrial skills and experience during their course of study;

2. Prepare students for the work situation they are likely to meet after graduation;

3. Expose the students to work methods and techniques in handling equipment and machinery that may not be available in their institutions;

4. Allow the transition phase from school to the world of working environment easier and facilitate students' contact for later job placements and

5. Provide students with an opportunity to apply their theoretical knowledge in real work situation thereby bridging the gap between theory and practice.

\section{Skill Development and Acquisition in Agricultural Education Programme}

In order to bridge the gap between theory and practice, the students need to acquire skills so as to put to practice the concepts learnt theoretically. Skills according to Robinson (2000) is any psychomotor, manipulative and technical tasks needed for performance in many given occupation which could be acquired through observation, training and learning. Skills are human capability of performing technical work very well with dexterity and competence. Skills could also be defined as the ability of a person to perform an act expertly.

Osinem, (2008) described skill as that expertise, practice and ability or proficiency displayed in the performance of a task. It involves the acquisition of performance capability through repetitive performance of an operation.

Skill acquisition is the process of gaining effective and ready knowledge in developing one's aptitude and ability in a particular field. It is one among other policies embarked upon in Nigeria with the sole aim of reducing poverty, crime corruption rate, rural and urban drift, unemployment and other social vices.

Acquisition of practical skills as explained by Idoko (2014) involves the development of new skills, practice and ways of doing things or performing a task, usually gained through training or experience. From the foregoing, practical skills acquisition could be referred to as an organized process of training which eventually leads to effectiveness in a given trade. It is an ability to do a given job better and faster with enhanced output. This is the fundamental objective of SIWES which is not farfetched from the objectives of Agricultural Education programme in Colleges of Education. Okwelle and Ojutule (2018) stated that lack of these skills is frustrating to the industrial sector and its effects are equally grave on the society in all spheres of the economy. Skill acquisition however, cannot be achieved in SIWES without involving the resource inputs (The Human and Material components) needed to acquire the skills. This paper focuses only on the human components of the resource inputs.

\section{Human Resource Inputs Need in (SIWES) in Agricultural Education Programme}

Human resource inputs are the total experience, skills, talents and knowledge of people which are applied to production of goods and rendering of useful services. They include individual with versatile knowledge, cognate experience in the field of production of agriculture and pedagogy education. Human resources according to Osarobo (2002) could be seen as the total supply of persons available and fitted for 
services. Osinem (2008) affirmed that human resource inputs into Agricultural Education and Training are personnel such as lecturers (institution supervisors), instructors, farm attendants (industry-based supervisors) that assist in imparting knowledge and skills to learners. The human resource inputs in the context of this paper also include SIWES Coordinators and Industrial Training Fund (ITF) personnel.

The human component of resource inputs interact with the students during SIWES at certain time to bring about production of output. The quality and quantity of this output are to a greater extent dependent on the availability, adequacy and functionality of the human component of the resource inputs. Resource inputs are guided by policies in the minimum standard document of NCCE of Colleges of Education. These policies embrace areas such as availability, adequacy and functionality of the resource inputs.

Availability of resource inputs in the context of this paper has to do with the quantity of human resource inputs that should be made available for the implementation of SIWES through Agricultural Education programme in Colleges of Education. Adequacy of resource inputs deals with the quantity of human resource inputs that is enough or sufficient for training of Agricultural Education students in SIWES programme. Functionality of resource inputs is the worth or quality of performance of the available and adequate human resource inputs for training Agricultural Education students in SIWES programme (Onipede, 2013).

One of the areas of concern is the availability and effectiveness of the industry-based supervisors at the agro-based industries to take up the students in the appropriate tasks and skills to be taught. Observations have shown that some are not being motivated to take the students because of lack of incentives in terms of remunerations. In places where the industry-based supervisors are available and are ready to train the students, their numerical strength might be of low influx. In a situation where they are adequate to train the students, most of the tools, equipment and machine needed by the students might be inadequate rendering the industry-based supervisors non-functional. It has been observed that in places where the industry-based supervisors are available, adequate and should be functional, some never give the needed training to the students. They sometimes assign the SIWES students some works that are not relevant to what they have come to do. Observations have also shown that some of the female students are sometimes been harassed by the male industry-based supervisors.

It has been observed that thorough supervision of students on SIWES by institution supervisors and ITF personnel is not regularly done. At times, the institution supervisors and the ITF personnel often find it difficult to pay regular visits to these students due to far distances of their placements and problem of mobility. This might make the students to be unserious during SIWES since they know that the availability of the supervisors to supervise them as at when due is uncertain thereby, resulting to low skill acquisition by the students.

Umoh (2000) found out in a study on the evaluation of the implementation of Students Industrial Work Experience Scheme (SIWES) in Agriculture, that the implementation of the programme by the Colleges of Education was not effective. He added that the SIWES Coordinators appointed by the College authorities to man the central SIWES Coordinating Units in the Colleges were not professionally and academically competent. Another study conducted by Adekola (2001) on evaluation of SIWES supervision found out that the industrybased supervisors hardly give adequate supervision to students and that the ITF supervisors did not visit students on SIWES for supervision.

\section{Conclusion}

The inputs given by the human components of the resource inputs in Students Industrial Work Experience Scheme (SIWES) in Agricultural Education programme can never be over emphasized. The training and skills to be acquired in SIWES are just like a robot, which cannot perform on its own, unless it is been remote. Not until the SIWES coordinators, institution supervisors, industry-based supervisors and Industrial Training Fund (ITF) personnel are made available, adequate and functional, no training would be done and no skill would be acquired. There is therefore the need to ensure availability, adequacy and functionality of the human resource inputs for skill development and better SIWES implementation in Agricultural Education programme of Colleges of Education in Nigeria.

\section{Recommendations}

It was recommended that: 
1. Students should be placed on industrial work experience relevant to their course of study.

2. The procedure for student placement should be improved greatly

3. SIWES supervision should be carried out on regular basis.

4. Industrial supervisors should endeavour to discuss training plans and students' progress with the industrybased supervisors during SIWES programme.

4 There should be occasional visitation of professionals and resource persons to speak on career and industrial related issues during SIWES programme.

5. The ITF should outline specific role expectations of the College-based Supervisors in SIWES programme implementation in agriculture.

6. NCCE and the ITF should set up independent implementation teams to monitor the implementation of SIWES to ensure strict compliance to the ITF approved guidelines on SIWES.

\section{References}

Abraham-Ibe I.G., (2014). The inclusion of SIWES in OTM curriculum and its challenges. A Conference Proceedings of the 2nd National Conference of the School of Business Education, Federal College of Education Technical, Akoka, Lagos pp.120-130.

Adekola, Y.A.,(2001). Evaluating of SIWES Supervision in Delta State. Unpublished M.Ed Thesis, University of Nigeria, Nsukka.

Akerejola O.(2008) Information and Guidelines for Students Industrial Work Experience Scheme Http://www.itfnigeria.org|docs|siwes-op-guide.pdf Aregbesola, R. (2018, March 12) Training Teachers to raise Education Standard - The Nation

Famiwole, R.O \& Adu, F.O. (2013) Introduction to Agriculture: PETOA Educational Publishers, Ado-Ekiti Idoko CU (2014). Skill acquisition and youth empowerment in Nigeria. Global Journal of Commerce \& Management Perspective 3(1):51-54.

Industrial Training Fund (2004). Information and Guidance for Students Industrial Work Experience Scheme: Reviewed, ITF, Jos Nigeria

James, E.E. \& Robinson O.O. (2017). Technical and Vocational Education and Training Skills: An Antidote for Job Creation and Sustainable Development of Nigeria Economy. Problems of Education in the $21^{\text {st }}$ Century, 75(6) 535-549.

National Commission for Colleges of Education (NCCE, 2009). Minimum Standard for Nigeria Certificate in Education: Vocational Technical Education (4th ed). Abuja:

NCCE.

Njoku CA (2014). Automation in industry and curriculum review needs of mechanical engineering craft practice students in technical colleges in Lagos State. An Unpublished M.ED. Thesis, University of Nigeria Nsukka.

Ogbuanya, T. C., Njoku, C.A., Kemi, P. O.\& Ogunkelu, M. O. (2018). Evaluating the effectiveness of Students Industrial Work Experience Scheme (SIWES) programme to ensure quality of technical, vocational education and training in technical colleges in Lagos State. International Journal of Vocational and Technical Education Vol. 10(7), 61-69

Okwelle PC, Ojutule DI (2018). Constraints to students' effectiveness in practical skills acquisition in technical colleges in Kogi State, Nigeria. International Journal of Innovative Scientific and Engineering Technologies Research 6(1):1-9.

Onipede, O. (2013). Effectiveness of Resource inputs into the implementation of Agricultural Education Programme in College of Education in Southwest Nigeria.

Osarobo, L.O. (2002). Research in Vocational/Technical Education in Nigeria Department of Industrial Technology Education, University of Benin. Ese Press, Ekekwan campus, Benin city, Nigeria. 
Osinem,E.C. (2008). Managing Agricultural Education and Training: Resources, Principles and Methods. Enugu: Belony International Publishers.

Robinson, J. P., (2000). What are employability skills?" Alabama Cooperative Extension System: A Fact Sheet. The Work Place 3(1)1-3

Taiwo, E. A. (2016, June 13). SIWES: The genesis and influence on national growth and development. Retrieved from http://eduregard.com/wpcontent/uploads/2016/04/SIWES-students-1.pdf

Umoh, M.I. (2000). Evaluation of the Implementation of Students Industrial Work Experience Scheme (SIWES) in Agriculture in Colleges of Education in Eastern Nigeria. Unpublished Ph.D Thesis, University of Nigeria, Nsukka. 